\title{
Control of the transmission length in the prestressed hollow-core slabs using values of the strand end slip
}

\author{
Victor Tur ${ }^{1}$, Stanisław Fic ${ }^{2}$ \\ ${ }^{I}$ Department of Concrete Technologies, Faculty of Civil Engineering, Brest State Technical \\ University,e-mail: vvtur@bstu.by \\ 2 Department of General Building Engineering, Faculty of Civil Engineering and Architecture, \\ Lublin University of Technology,e-mail: s.fic@pollub.pl
}

\begin{abstract}
It is shown [1] that even though the production of precast pre-tensioned concrete elements started more than 50 years ago, no one has ever succeeded in determining the real transmission length or in obtaining adequate measures to control it, due to the quality of the production. These arrears are confirmed by the study of existing standards.

In general, it is assumed that the measurement of the magnitude of the slippage of strand at the end of hollow core prestressed slab is an indirect method of estimation and control of the value of the transmission length. One should mention that EN1168 and EN13369 that regulate requirements of designing and production of hollow-core slabs are applied as the method of control. Based on a particular bond-slip relation for strands, a nonlinear equation is developed for the transmission length and for the slippage of prestressed strand, taking into account such factors as the concrete strength at transfer, the degree of the initial prestress type and diameter of tendons. These equations have been used for the control of transmission length of the strands calculated by different methods available recently, including a code provision. Then they were compared to measured data, obtained in production control of the hollow-core slabs.
\end{abstract}

Keywords: Hollow-core slabs, transmission length, slippage, strand.

\section{Introduction}

The calculation of transmission length of prestressing strands is very important and essential for the design of prestressed hollow core slabs that are produced in accordance with EN1168 [2].

The force in prestressing strand is transferred by bond to the concrete in the release operation. At this stage, strand stress varies from zero at the free end of member to a maximum value (effective stress).

Variation in strand stress along the transfer length involves a slip between the strand and the concrete. As it was shown [3,4] the measurements of strand a end slip are an indirect method for determining the transfer length. Most experimental standards $[5,6]$ are based on this method, and it was proposed as a simple non-destructive assurance procedure by which the quality of bond can be monitored within precasting plants [4].

$$
l_{p t}=\alpha \frac{\delta_{e}}{\varepsilon_{p, i}}
$$

Guyon [7] proposed the following expression from a theoretical analysis where $l_{p t}$ - is the value of the transmission length; $\delta_{e}$ - is the strand end slip at the free end of a prestressed concrete member; $\varepsilon_{p, i}$ - is the initial strain of a strand just before the release of prestress; $\alpha$ - coefficient represents the shape factor of the bond stress distribution along the transmission zone (in accordance with [3] two hypotheses were considered: $\alpha=2$ for a uniform bond stress distribution - linear variation in strand stress; $\alpha=3$ for a linear descending bond stress distribution parabolic variation in strand stress). 
Equation (1) can be rewritten as follows:

$$
l_{p t}=\alpha \frac{E_{p}}{\sigma_{m p, i}} \delta_{e}
$$

where $\mathrm{E}_{\mathrm{p}}$ - is the modulus of elasticity of prestressing strands; $\sigma_{m p, i}-$ is the strands stress immediately before the release.

The relationship (2) can be used to calculate the transmission length based on the slippage value of the strand measures at the end of the element. To achieve this objective, a determinated value for $\alpha$ must be taken. The value may be calculated by measuring the transmission length and the strand slippage simultaneously.

As it was shown in [3], several researchers have proposed different values of $\alpha$ for the bond stress distribution along the transfer zone from experimental results and theoretical studies (see table 1).

Equation (1) has already been suggested as a criterion for the guarantee of the production quality of elements prestressed by pre-tensioning $[1,3,8]$.

In accordance with EN 1168:2005+A3:2011 (table A3), finished product inspection for the sawn hollow-core slabs consists of visual inspection of all elements, and if there is no doubt of measuring three strands per production day. However, in the case of doubt measuring, of all concerning strands is required. The criteria for the control of strands slippage must be taken in accordance with EN 13369 [6].

In accordance with [6] slippage, which is the shortening of the tendon after the transfer of the prestressing force, should be limited to the following values:

for individual tendon (strand or wires):

$$
\delta_{e} \leq 1.3 \Delta L_{0}
$$

for mean value for all tendons in an element:

$$
\delta_{e} \leq \Delta L_{0}
$$

In general, slippage of tendons is measured only on sawn products [24], like hollowcore slabs (p. 4.2.3.2.4).

In accordance with EN 13369 (p.4.2.3.2.4), the value of basic slippage $\Delta L_{0}(\mathrm{MM})$ should be calculated:

$$
\Delta L_{0}=0.4 \frac{\sigma_{p m, 0}}{E_{p}} l_{p t, 2}
$$

where $1_{\mathrm{pt} 2}$ - is the upper bond value of transmission length $=1,2 \mathrm{~L}_{\mathrm{pt}}$ in millimeters according to EN $1992-1-1 ; \sigma_{p m, 0}$ - is the initial stress in prestressing steel immediately after the release, $\mathrm{MPa} ; \mathrm{E}_{\mathrm{p}}$ - is the modulus of elastic of the prestressing steel, in $\mathrm{MPa}$.

Yet in line with MC 2010 - Final Draft [9] (p.6.1.8.4), the transmission length can be estimated from the slippage value $\left(\delta_{e}\right)$ of the tendons at the end face of the tendons and at the end face of the concrete member. However, when the concrete member is sawn from a longer production unit, the slippage cannot be estimated properly. Assuming a linear stress distribution along the transmission length, this slippage is:

$$
\delta_{e}<0,5 \frac{\sigma_{p m, 0}}{E_{p}} \cdot l_{b p t}
$$

It should be mentioned that in formula (5) according to the EN 13369 [6], a multiplier 0.4 is used to compute $\Delta \mathrm{L}_{0}$, which corresponds to $\alpha=2.5$ coefficient in formula (2), in contrast to MC 2010 [9] when the value of $\alpha=2$ is proposed. It is a very uncommon situation.

\section{Choice of $\alpha$-coefficient value}

The investigations carried out by J.R. Marti-Vergas and other [3] reveal that the Guyon's relation to the coefficient $\alpha=2,44$ (Table 3 ) shows the best result among the 
relationships represented in Table 1 as for wide range of the slippage values (depending on the concrete strength at the time of release, distribution of tendons).

The relative transmission length $\beta$ according to the standards and advisable calculated values of transmission length, expressed relative to the nominal diameter according to the codes, is shown in the Table 2.

The design value of transmission length expected in American Standards is based on the Cousins, Zia and Johnson's research results [10]. The research result has shown that standard ACI 318 [11] underestimate both the transmission lengths and anchorage zone of strand. Thus is comparison with $1_{\mathrm{pt}}=50 \varnothing$ expected in ACI 318, a measured length for strand $\varnothing 12.7 \mathrm{~mm}$ is changed from $1250 \mathrm{~mm}(99.4 \varnothing)$ to $1880 \mathrm{~mm}(148 \varnothing)$. Hence, FHWA was published in the Memorandum using the results of the research in accordance with FHWA Memorandum $\varnothing 15.2 \mathrm{~mm}$ where strands without anchors were forbidden and anchorage zone was enhanced by $60 \%$.

Table 1. Relationship between the transmission length and the value of slippage [3]

\begin{tabular}{ccc}
\hline № . & Source & Relationship \\
\hline 1 & $\begin{array}{c}\text { Marshall, } \\
\text { Krishnamurthy } \\
(1969)\end{array}$ & $l_{p t}=\frac{\delta}{K}$ \\
\hline 2 & $\begin{array}{l}\text { Balázs } \\
(1992)\end{array}$ & $l_{p t}=105 \cdot \varnothing \sqrt[4]{\frac{\delta^{3 / 2}}{f_{c}^{\prime}}}$ \\
\hline 3 & $\begin{array}{l}\text { Balázs } \\
(1993)\end{array}$ & $l_{p t}=\frac{111 \cdot \delta^{0,625}}{f_{c i}^{0,15}\left(\frac{f_{p i}}{E_{p}}\right)^{0,4}}$ \\
\hline 4 & $\begin{array}{c}\text { Rose, Russel } \\
(1997)\end{array}$ & $l_{p t}=2 \delta \frac{E_{p}}{f_{p i}}+137,16$ \\
\hline
\end{tabular}

It should be noted that the results of measurements of the transmission length performed by different authors (Table 5) have a significant spread for the strands that have the same diameter when the concrete compressive strength at the time of release and initial force transfer is similar and when the forces of prestress are similar.

It should also be stated that the tables in which the length of transmission zone was presented in relation to the nominal diameter of strand depending on the value of concrete strength at the time of release. Moreover, the types of tendon (Table 7) were included in the edition of EC2 (ENV-1992).

As it was assumed in EN 1992-1-1 [13], the design values of the transmission zone length are calculated by multiplying the basic value of transmission length by 0,8 and 1,2 coefficients.

The above introduced approach, in which the basic value of the transmission length is $1_{\mathrm{pt}}=\beta_{\mathrm{d}} \varnothing$, has a number of imperfections.

It should be noted that parabolic distribution of the steel stress along a transmission length was used when defining the value of $\beta_{\mathrm{d}}$, introduced in ENV 1992; while EN 1992-1 [13] and MC 2010 assume a "more realistic" [8] linear distribution. 
Table 2. Values of $\alpha$-coefficient in Guyon formula (2) suggested by different researchers [3]

\begin{tabular}{cccc}
\hline Reference & Coefficient $\alpha$ & \\
\hline FIP (1982) & 4,0 & & $\begin{array}{c}\text { Indicative value (sudden } \\
\text { transfer) }\end{array}$ \\
\hline Guyon (1953) & & 3,0 & $\begin{array}{c}\text { Assumed value when fpi - } \\
\text { just after the prestress release }\end{array}$ \\
\hline FIP (1982) & & 2,86 & Experimentally \\
\hline Olesniewicz (1975) & 2,86 & Experimentally \\
\hline FIP (1978) & 2,8 & Assumed value \\
\hline BILEM (1979); IRANOR (1982); LCPC (1999) & $2 /(1-$ b) $\alpha$ & Theoretical investigations \\
\hline Balázs (1993) & $2,3 \ldots 2,6$ & $\begin{array}{c}\text { Experimental and theoretical } \\
\text { investigations }\end{array}$ \\
\hline den Uijl (1998) & 2,5 & Assumed value \\
\hline Jonsson (1992) & & \\
\hline $\begin{array}{c}\text { Guyon (1953); Brooks et al (1988); Balogh (1992); } \\
\text { Russel and Burns (1996); Logan (1997); Steinberg et } \\
\text { al (2001); Oh and Kim (2000); Wan et al (2002); } \\
\begin{array}{c}\text { CEB-FIP (1993); Rose and Russel (1997); den Uij1 } \\
\text { (1998); fib (2000); Lopes and Carmo (2002) }\end{array}\end{array}$ & 1,0 & \\
\hline
\end{tabular}

Table 3. Comparison of observed values and calculated values of the transmission length [3]

\begin{tabular}{ccc} 
& Mean value $l_{p t, \text { cal }} / l_{\text {pt,mear }}$ & Correlation coefficient $\mathrm{R}^{2}$ \\
\cline { 2 - 3 } Relationship acc. [12] & 1,18 & 0,07 \\
\cline { 2 - 3 } & 1,17 & 0,54 \\
\cline { 2 - 3 } & 1,11 & 0,35 \\
\cline { 2 - 3 } & 1,01 & 0,21 \\
\hline Guyon formula when $\alpha=2.44$ & 0,95 & 0,20
\end{tabular}

Table 4. The relative transmission length $\beta$ according to the standards and codes (for seven-wire strands) [12]

\begin{tabular}{|c|c|c|c|c|}
\hline \multirow[t]{2}{*}{ Standard } & \multirow{2}{*}{$\begin{array}{l}\text { Steel stress } \\
\text { and } \\
\text { release, } \\
\mathrm{MPa}\end{array}$} & \multicolumn{3}{|c|}{$\begin{array}{l}\text { Length of transmission zone } l_{p t}-\text { nominal diameter of a strand ratic } \\
\left.\qquad \beta=l_{p t} / \varnothing\right) \text { just after release for mean value of the concrete } \\
\text { compressive strength } f_{c m, 0}, \mathrm{MPa}\end{array}$} \\
\hline & & 30 & 40 & 50 \\
\hline $\begin{array}{c}\text { ASO [14] } \\
\varnothing 12,5 \mathrm{~mm} \text { strand }\end{array}$ & 1450 & $183 / 11,2$ & $135 / 8,4$ & No data \\
\hline ACI-318R [11] & 1400 & $66 / 3,5 *)$ & $66 / 3,5$ & $66 / 3,5$ \\
\hline BS 8110 [15] & $\leq 0,75 \mathrm{f}_{\mathrm{pk}}$ & $44 / 2,3$ & $38 / 1,7$ & $34 / 1,4$ \\
\hline EN 1992-1 [13] & $\geq 1200$ & $70 / 3,5$ & $60 / 2,7$ & No data \\
\hline NEN 6720 [16] & 1450 & $66 / 4,0$ & $59 / 3,6$ & No data \\
\hline $\mathrm{PN} 84 / \mathrm{B}$ [17] & 1350 & $78 / 4,4$ & $61 / 3,5$ & No data \\
\hline СНиП 2.03.01 [9] & 1000 & $63 / 3,6$ & $53 / 2,9$ & - \\
\hline
\end{tabular}

The final version of EN 1992 (p.8.10.2) [13] comprises a computing method that fully replicates the method from MC 2010 (p.6.1.8) (Table 7).

In accordance with EN 1992-1-1 [13] and Building Code of Belarus 5.03.01 [18] the value of the transmission length is:

$$
l_{p t}=\alpha_{1} \cdot \alpha_{2} \cdot \frac{\sigma_{p m, 0} \cdot \varnothing}{\eta_{p 1} \cdot \eta_{1} \cdot f_{c t d}(t)},
$$


where $\alpha_{1}=1,0 ; \alpha_{2}=0,19 ; \eta_{1}=1,0 ; \eta_{\mathrm{p} 1}=3,2$ for strands; $f_{c t d}(\mathrm{t})$ - is the design value of concrete tensile strength at the time of release.

Table 5. Experimental values of the transmission length for $\emptyset=12.5 \mathrm{~mm}$ strands [19]

\begin{tabular}{|c|c|c|c|c|c|c|c|}
\hline $\begin{array}{l}\text { № } \\
\text { p. }\end{array}$ & Reference & $\begin{array}{l}\text { Force } \\
\text { transfer } \\
\text { type }\end{array}$ & $\begin{array}{l}\text { Mean value of } \\
\text { concrete strength } \\
\text { at release fcm }(t) \text {, }\end{array}$ & $\begin{array}{l}\text { Numb } \\
\text { er of } \\
\text { experi }\end{array}$ & $\begin{array}{c}\text { Transmissi } \\
\text { on length } \\
\text { lpt, mm }\end{array}$ & $\begin{array}{l}\text { № } \\
\text { p. }\end{array}$ & $\begin{array}{l}\text { Referen } \\
\text { ce }\end{array}$ \\
\hline & & & & & Low & Aver & High \\
\hline 1 & $\begin{array}{c}\text { Hanson, Kaar } \\
(1959)\end{array}$ & \multirow{7}{*}{$\begin{array}{l}\text { Cutting } \\
\text { with the } \\
\text { help of } \\
\text { flame }\end{array}$} & 36,61 & 17 & - & 660,4 & - \\
\hline 2 & $\begin{array}{c}\text { Kaar and other } \\
(1963)\end{array}$ & & 23,72 & 10 & 812,8 & 962,7 & 1104,9 \\
\hline 3 & Hanson (1969) & & 34,19 & 2 & - & 609,6 & - \\
\hline 4 & $\begin{array}{l}\text { Consins and } \\
\text { other (1990) }\end{array}$ & & 29,92 & 20 & 812,8 & 1262,4 & 1879,6 \\
\hline 5 & $\begin{array}{l}\text { Malik (1990) } \\
\text { Russel, Burns }\end{array}$ & & 24,68 & 12 & 558,8 & 1066,8 & 1625,6 \\
\hline 6 & $\begin{array}{c}\text { Unay and other } \\
\text { (1991) } \\
\text { Russel, Burns }\end{array}$ & & 30,2 & 34 & 406,4 & 762,0 & 1117,6 \\
\hline 7 & $\begin{array}{l}\text { Shahawy and } \\
\text { others (1992) }\end{array}$ & & 35,23 & 12 & 749,3 & 764,5 & 812,8 \\
\hline 8 & $\begin{array}{l}\text { Mitchell and } \\
\text { others (1993) }\end{array}$ & $\begin{array}{l}\text { Gradual } \\
\text { force } \\
\text { transfer }\end{array}$ & 40,47 & 14 & 330,2 & 500,38 & 711,2 \\
\hline 9 & $\begin{array}{c}\text { Consins and } \\
\text { others (1993) }\end{array}$ & \multirow{2}{*}{$\begin{array}{l}\text { Cutting } \\
\text { with the } \\
\text { help of } \\
\text { flame }\end{array}$} & 44,88 & 27 & 685,8 & 1153,2 & 1727,2 \\
\hline 10 & $\begin{array}{l}\text { Deatherage and } \\
\text { others (1994) }\end{array}$ & & 34,2 & 16 & 457,2 & 602,0 & 914,4 \\
\hline 11 & Byuno Hwan & \multirow{4}{*}{$\begin{array}{l}\text { Gradual } \\
\text { force } \\
\text { transfer } \\
\text { (single } \\
\text { strand). }\end{array}$} & 35,0 & 20 & - & 651,0 & - \\
\hline 12 & $\begin{array}{l}\text { Oh and others. } \\
\text { (2001) } \\
\text { (monostrand) }\end{array}$ & & 45,0 & 20 & - & 548,0 & - \\
\hline 13 & Byuno Hwan & & 35,0 & 20 & - & 661,0 & - \\
\hline 14 & $\begin{array}{c}\text { Oh and others } \\
(2002) \\
\text { (twinstrand) }\end{array}$ & & 45,0 & 20 & - & 577,0 & - \\
\hline 15 & $\begin{array}{c}\text { J. Marti-Vargas } \\
\text { and others } \\
(2007)\end{array}$ & $\begin{array}{c}\text { Gradual, } \\
\text { step-by- } \\
\text { step } \\
\text { method } \\
\text { ECADA }\end{array}$ & $26,1 \ldots 54,8$ & 48 & 400,0 & 515,0 & 550,0 \\
\hline
\end{tabular}

Table 6. Values of $\beta$ b coefficient for the basic value of transmission length according to the EN 1992-1-1

\begin{tabular}{cccccccc}
\hline $\begin{array}{c}\text { Mean value of compressive strength of } \\
\text { concrete at the time of release, MPa }\end{array}$ & 25 & 30 & 35 & 40 & 45 & 50 \\
\hline \multirow{2}{*}{$\beta$} & Strands, smooth wires & 75 & 70 & 65 & 60 & 55 & 50 \\
\cline { 2 - 7 } & wires idented and crimped & 55 & 50 & 45 & 40 & 35 & 30 \\
\hline
\end{tabular}

After substituting corresponding values, the formula (6) can be rewritten as follows:

$$
l_{p t}=1 \cdot 0,19 \cdot \frac{\sigma_{p m, 0} \cdot \varnothing}{1,0 \cdot 3,2 \cdot f_{c t d}(t)}=\frac{\sigma_{p t, 0} \cdot \varnothing}{16,84 \cdot f_{c t d}(t)}
$$


When the value $f_{c t d}(\mathrm{t})$ is equal to $1.35 \mathrm{~N} / \mathrm{mm}^{2}$ for the concrete compressive strength at release $f_{c, \text { cube }}(\mathrm{t})=40 \mathrm{MPa}$, the design value of the transmission length is equal:

$$
l_{p t}=\frac{\sigma_{p m, 0} \cdot \varnothing}{22,73}
$$

Table 7. Comparison of models for design value of transmission for the length according to MC 2010 and EN 1992-1-1

\begin{tabular}{|c|c|c|}
\hline Parametr & MC 2010, p. 6.1.8 & EN 1992, p. 8.10.2 \\
\hline $\begin{array}{l}\text { Basic } \\
\text { anchorage } \\
\text { length }\end{array}$ & $\begin{array}{c}l_{b p}=\frac{A_{s p}}{\pi \varnothing} \cdot \frac{f_{p t d}}{f_{b p d}}, \text { where } \\
\frac{A_{s p}}{\pi \varnothing}=\left(\frac{1}{4}\right) \varnothing \text { - for tendon with circular cross- } \\
\frac{A_{s p}}{\pi \varnothing}=\left(\frac{7}{36}\right) \varnothing \text {-for seven-wire strands } \\
f_{b p d}-\text { design value of bond strength }\end{array}$ & $\begin{array}{l}\text { Is not used as a single parameter } \\
\text { in p. } 8.10 .2\end{array}$ \\
\hline $\begin{array}{l}\text { Bond } \\
\text { strength }\end{array}$ & $\begin{array}{c}f_{b p d}=\eta_{p 1} \cdot \eta_{p 2} \cdot f_{c t d}(t), \text { where } \\
\eta_{p 1}=1,4-\text { for indented and crimped wires; } \\
\eta_{p 1}=1,2-\text { for seven-wire strands; } \\
\eta_{\mathrm{p} 2}=1,0-\text { good bond conditions; } \\
\eta_{\mathrm{p} 2}=0,7-\text { other bond conditions; } \\
f_{c t d}(t)-\text { design value of concrete tensile strength }\end{array}$ & $\begin{array}{c}f_{b p d}=\eta_{p 1} \cdot \eta_{1} \cdot f_{c t d}(t) \\
\eta_{\mathrm{p} 1}=2,7-\text { for indented and } \\
\text { crimped wires; } \\
\eta_{\mathrm{p} 1}=3,2-\text { for seven-wire strands; } \\
\eta_{1}=1,0-\text { good bond conditions; } \\
\eta_{1}=0,7-\text { other bond conditions. }\end{array}$ \\
\hline $\begin{array}{l}\text { Transmissi } \\
\text { on length }\end{array}$ & $\begin{array}{c}l_{b p t}=\alpha_{p 1} \cdot \alpha_{p 2} \cdot \alpha_{p 3} \cdot l_{p t} \cdot \sigma_{p i} / f_{p t d}, \text { where } \\
\alpha_{p 1}=1,0-\text { gradual release; } \\
\alpha_{p 2}=1,0-\text { for calculation of anchorage length; } \\
\alpha_{p 3}=0,5-\text { for strands. }\end{array}$ & $\begin{array}{c}l_{p t}=\alpha_{1} \cdot \alpha_{2} \cdot \emptyset \cdot \sigma_{p i} / f_{b p t}, \text { where } \\
\alpha_{1}=1,0-\text { gradually } \\
\alpha_{2}=0,25 \text { - for circular; } \\
\alpha_{2}=0,19-\text { for seven-wire strands }\end{array}$ \\
\hline
\end{tabular}

It is relevant to compare the equation (9) to the formula suggested by ACI 318 [11] for hollow-core slabs:

$$
l_{p t}=\frac{\sigma_{p t, \infty} \cdot \varnothing}{20,7}
$$

where $\sigma_{p t, \infty}$ - is the stress in steel after all losses.

Taking into account the design transmission length in accordance with ACI 318 [11] allows to determine two limiting values of a slippage for hollow-core slabs:

$$
\begin{aligned}
& \delta_{e, a l l}=\frac{1}{41,4} \cdot \frac{\sigma_{p m, i}}{E_{p}} \sigma_{p m, \infty} \cdot \varnothing-\text { when } \alpha=2 \\
& \delta_{e, a l l}=\frac{1}{62,1} \cdot \frac{\sigma_{p m, i}}{E_{p}} \sigma_{p m, \infty} \cdot \varnothing-\text { when } \alpha=3
\end{aligned}
$$

The most favourable value is chosen depending on the designed situation.

It should be pointed out that the Building Code of Belarus 5.03.01 [18] and EN 19921-1 [13] also recommend to determine the upper and the lower value of the transmission length $\left(l_{p t 1}=0,8 l_{p t}\right.$ and $\left.l_{p t 2}=1,2 l_{p t}\right)$. Such values are accepted according to the recommendations of Wolfer and Kruger's research results and suggest taking into account the deviations of mean values of measured relative strength of concrete. 
It needs to be noticed that appearance of a concrete tensile strength while determining so important a parameter in bond law is an uncommon phenomenon, which is also underlined in the research paper [12].

The mean value of concrete tensile strength should be determined by means of results of a production control test of concrete samples at the time of release. Then if the required minimum concrete compressive strength at the time of release is $40 \mathrm{MPa}$, the mean value of tensile strength should be $f_{c t m}(\mathrm{t})=2,9 \mathrm{MPa}$ and a basic value of a transmission length should be:

$$
l_{p t}=1 \cdot 0,19 \cdot \frac{\sigma_{p m, 0} \cdot \varnothing}{1,0 \cdot 3,2 \cdot f_{c t d}(t)}=\frac{\sigma_{p m, 0} \cdot \varnothing}{48,8}
$$

The upper value of $l_{p t}$ can be accepted:

$$
l_{p t}=30 \cdot \varnothing_{\text {nom }}
$$

This value can be used during the control of hollow-core slabs if:

- the compressive strength of concrete at the time of release is no less than $f_{c t m}(\mathrm{t})=$ $40 \mathrm{MPa}$;

- the initial steel stress at the time of release is no more than $1100 \mathrm{MPa}$.

The figure 1 shows the comparison of experimental and calculated values of a slippage of strands calculated with the use of the accepted preconditions from the Building Code of Belarus 5.03.01 [18] and EN 1992, ACI 318 [11] for hollow-core slabs, when the slabs are sawn from a longer production units.

As it arises from the comparison above (Fig.1), both methods show quite conservative result concerning the outcomes received for $\emptyset=12,7 \mathrm{~mm}$ strands when estimating the transmission zone length.

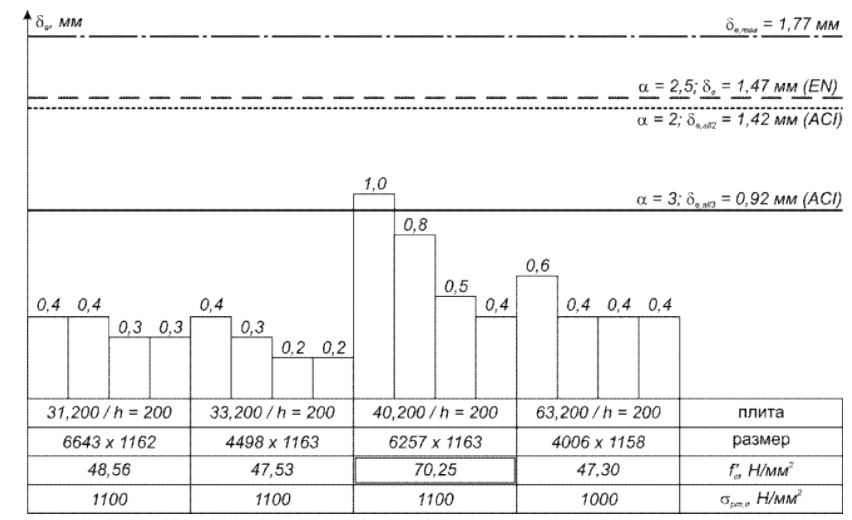

Fig. 1. Comparison of experimental and calculated values of slippage

\section{Conclusions}

The relations recommended by EN 13369 [6] can be used for the control of a transmission length with the use of the magnitude of a slippage during the hollow-core slabs production.

1. The strand slippage values relative to the concrete, at the end of the hollow-core prestressed slab, were studied. The relationships recommended by EN 13369 [6] can be used for the production control of the transmission length in prestressed hollow core slabs;

2. For the calculation of the basic transmission length in equation (7), mean value concrete tensile strength should be used.

3. Admission of $\alpha=2,5$-coefficient in Guyon formula (2) (multiplier 0.4 in the formula (3) is reasonable and proved by the experimental data [3]). For the calculation of the basic transmission length in equation ( ), mean value tensile concrete strength should be used. 
For the above defined production condition for the hollow-core slabs $\left(\sigma_{p m, 0}=\right.$ $1100 M P a$, and $\left.f_{c m}(\mathrm{t}) \geq 40 M P a\right)$, the equation $l_{p t}=30 \varnothing_{\text {nom }}$ can be used.

\title{
References
}

1 Bruggeling A.S.G. Transmission of prestress by bond/ Internal Report of TG9.4 to Commission.$2000-37 \mathrm{p}$.

2 EN 1168:2006 - Precast Concrete Products - Hollow Core Slabs.

3 PCI Manual for the design of Hollow Core Slabs/ Second Edition, PCI, Chicago, $1988-120$ p.

4 Oh B.H., Kim E.S., Kim S.K. Correct Prediction of Transfer Length in Pretensioned Prestressed Concrete Structures// Transactions, SMIRT16, Washington, DC, August 2001, Paper \# 1545.- p. $1-8$.

5 СТБ 1383. Плиты покрытий и перекрытий железобетонные для зданий и сооружений. Технические условия.

6 EN 13369 - Common rules for precast concrete products.

7 Gyon (1951) // Béton Précontraint, Paris, 1951.

8 Lopez M.R., Carmo N.F. Bond of prestressed strands to concrete: transfer rate and relationship between transmission length and tendon slippage / Structural Concrete.-2002, N 3 - p. 117-126.

9 Model Code 2010. Fib bulletin 55. 2011

10 Bruggeling. The transmission length of pretensioning prestressed steel. Proceeding Tenth International Congress of FIP, part 4, NewDelhi, India, 1986, page 117/127.

11 ACI Manual 318R-86 art. 12.9 - Interim, 1990 - USA - 278 p.

12 Bruggeling. Manual "Theorie en Praktijk van het vo orgespannen beton", 2 volumes 10050 p.- t. Koggeschip.

13 EN 1992-1-1. General Rules and Rules for Buildings: Section Four, art. 4.10. 9. NEN67201991. NNI Netherlands, art. 9.7, page 203.

14 AASHTO. American Association of State Highway and Transportation Officials/ Standard Specification for Highway Bridges.- 16th Edition, Washington D.C., 1996 - art. 9.28.

15 British Standard BS8110: Part 1: 1997, Section Four, art. 4.10.

16 NEN 6720

17 PN-84/B-03264, art. 8.2.3.

18 СНБ 5.03.01. Бетонные и железобетонные конструкции.

19 D.R. Rose, B.W. Russel. Investigation of Standardized Tests to Measure the Bond Perfomance of Prestressing Strand// PCI Journal.- Jily-August, 1997.- P. 56-62.

\section{Kontrola wartości długości zakotwienia cięgien w sprężonych płytach kanałowych przy użyciu wartości poślizgu splotów}

\author{
Victor Tur ${ }^{1}$, Stanislaw Fic ${ }^{2}$ \\ ${ }^{l}$ Katedra Technologii Betonu, Wydział Budownictwa, Brzeski Państwowy Uniwersytet Techniczny, e- \\ mail:vvtur@bstu.by \\ 2 Katedra Budownictwa Ogólnego, Wydział Budownictwa i Architektury, Politechnika Lubelska, e- \\ mail: s.fic@pollub.pl
}

Streszczenie: Bazując na szczególnej relacji przyczepność - poślizg dla splotów, opracowano równania nieliniowe dla długości zakotwienia i dla poślizgu sprężonych splotów przy uwzględnieniu czynników: wytrzymałości betonu, efektywności początkowego sprężenia i rozmiaru splotu. Te równania zostały użyte do skontrolowania długości zakotwienia sprężonych splotów obliczonych za pomocą różnych metod dostępnych $\mathrm{w}$ ostatnim czasie, uwzględniając zalecenia normowe, które zostały porównane z wynikami pomiarów uzyskanych podczas kontroli procesu produkcyjnego płyt kanałowych.

Słowa kluczowe: Płyty kanałowe, długość zakotwienia, poślizg, splot. 